Title Page

Of Floods and Droughts: The uneven politics of stormwater in Los Angeles

Joshua J. Cousins ${ }^{1}$

${ }^{1}$ Ecology, Evolution, Ecosystems and Society Program and Department of Geography and Environmental Studies Program, Dartmouth College, 6017 Fairchild, Hanover, NH 03755, USA; Joshua.j.cousins@dartmouth.edu

Corresponding author: Joshua J. Cousins, Ecology, Evolution, Ecosystems and Society Program and Department of Geography and Environmental Studies Program, Dartmouth College, 6017 Fairchild, Hanover, NH 03755, USA; Joshua.j.cousins@dartmouth.edu 


\section{Of Floods and Droughts: The uneven politics of stormwater in Los Angeles}

\section{$\underline{\text { Acknowledgements }}$}

I would like to thank all of those who took their time to contribute to this study including the interviewees, Josh Newell, Bilal Butt, Maria Carmen Lemos, and Scott Campbell. I also need to thank everyone who provided feedback at the Resiliency Workshops at the University of Michigan. I also want to thank the reviewers for their critical and constructive feedback. This research was supported by a Rackham Doctoral Research Grant; the Trent R. Dames Fellowship in the History of Civil Engineering at The Huntington Library, and the National Science Foundation \# 1536377. Any opinions, findings, and conclusions or recommendations expressed in this material are those of the author(s) and do not necessarily reflect the views of the National Science Foundation.

\section{Corresponding Author}

Joshua J. Cousins, Ecology, Evolution, Ecosystems and Society Program and Department of Geography and Environmental Studies Program, Dartmouth College, 6017 Fairchild, Hanover, NH 03755, USA; Joshua.j.cousins@dartmouth.edu 


\begin{abstract}
Stormwater is a complex political and geographical problem. It is at once bound to landuse decisions, tied to geographical features such as lakes and rivers, and capable of
\end{abstract} flowing across different political boundaries and jurisdictions. In this paper, I empirically focus on how disparate understandings of stormwater are forged through different institutional arrangements and the ways multiple actors interact across scales of governance in Los Angeles. The results indicate four discourses influence decisions on urban stormwater managements and are articulated through different forms of knowledge and power in environmental governance. The discourses diverge over contrasting perspectives on infrastructural interventions, the role of economic approaches, and the need for new institutions and rules. I suggest that disagreement may not deter integration and collaboration across different scales of governance, but without addressing conflict over key discursive claims about how stormwater governance should proceed, broadly accepted outcomes may remain elusive. With current trends in environmental governance moving towards hybrid forms that bring together groups that transcend traditional 
organizational structures, this paper reveals how more sustainable outcomes are being devised through current configurations of knowledge and power.

Keywords: Environmental governance; stormwater; Los Angeles; Discourse 


\section{INTRODUCTION}

Driven by the federal Clean Water Act (CWA) and the California Porter-Cologne Water Quality Control Act, as well as the impacts of urbanization on hydrological systems, stormwater is emerging as a critical issue facing cities across California. Along with aging infrastructure and development pressures, the anticipated increase in extreme drought and storm events associated with climate change are likely to have a profound impact on the full range of water management activities for cities not only in California, but also across the globe (EPA, 2014; Hanak \& Lund, 2011; IPCC, 2014). Scholars suggest that climate change will entail an entire reworking of urban water governance (Carlson, et al., 2015; Milly et al., 2008; Pahl-Wostl, 2007). In southern California, water managers are addressing this challenge by developing new technologies and management strategies to capture, recycle, and utilize stormwater as a beneficial resource. Rather than relying on traditional approaches employing logics of efficiency to convey water away from cities as quickly as possible in a centralized manner, many cities are implementing stormwater infrastructure through distributed or decentralized strategies that manage stormwater runoff closer to its source through low impact development (LID) and green infrastructure (GI) (Brown, Farrelly, \& Loorbach, 2013; Karvonen, 2011; Loperfido, et al., 2014).

These distributed and decentralized techniques present important tools for climate change adaptation planning and take on a variety of forms and names (Bell, 2015; Marlow, et al., 2013; Tompkins et al., 2010). Sustainable urban water management (SUWM), sustainable urban drainage systems (SUDS), integrated water resource 
management (IWRM), water sensitive urban design (WSUD) and enhanced watershed management planning (EWMP) all connote aspirations for changes in urban water management. While many of the details of these approaches may differ, they share a generalizable goal to manage the urban water cycle to garner multiple benefits, rather than single purpose targets typical of traditional water management approaches (Marlow et al., 2013). Stormwater management, for example, is increasingly looking to achieve both conveyance and infiltration to resolve water quantity and quality problems through site design strategies that replicate the functionality of the ecological and hydrological landscape of pre-urban conditions (EPA, 2001; Grimm et al., 2008; Pataki et al., 2011). Many of these approaches rely on hybrid governance arrangements that seek to establish collaborations among state agencies, communities, and market actors (Agrawal \& Lemos, 2007; Ferguson, Brown, \& Deletic, 2013; Porse, 2013; van de Meene, Brown, \& Farrelly, 2011). Hybrid governance is based on the rationale that no single agency or governmental entity retains the skills and capabilities to address the multiple and complex facets of environmental problems, such as stormwater (Lemos \& Agrawal, 2006). While it is becoming apparent that actors and organizations in multiple domains are needed to resolve these important environmental dilemmas, controversy remains as a result of water's multiple roles and functions in society as a flow resource. Water is also fixed to land through water rights and geographical features, such as lakes and rivers, but it is also mobile, capable of flowing across political boundaries or being transferred between basins. As Bakker (2014: 471) notes of water, "it is simultaneously an economic input, an aesthetic reference, a religious symbol, a public service, a private good, a cornerstone of public health, and a biophysical necessity for humans and ecosystems alike." The norms 
associated with each of these roles and functions directly and indirectly influences how local officials and residents develop their stormwater management practices (Carlson et al., 2015; Greenaway, et al., 2005). Some institutional norms lead actors to approach stormwater through technocratic or managerial approaches to improve social, environmental, and economic sustainability, and yet other norms lead to grassroots or bottom-up approaches to improve resource governance. The result presents difficulties for establishing new governmental, institutional, and technological structures to re-work the value and flow of stormwater due to the multi-scalar and multi-actor character of stormwater politics.

Given the diversity of governance approaches and perspectives operating at multiple scales to manage stormwater, and the difficulties this presents for collective action, exactly how do competing perspectives and institutional relationships relate to one another and influence how stormwater governance proceeds? I address this question by exploring how different 'expert' (policy makers, scientists, engineers, NGO leaders, etc.) discourses of stormwater governance options interact and conflict across multiple actors and across multiple scales of governance. My analysis reveals four discursive alignments. They share a narrative of developing integrated approaches that connect all of the institutions and sectors concerned with the management of water through science and data-driven methods. Discursive claims diverge around contrasting opinions of infrastructural interventions, the role of economic approaches, and the need for new institutions and rules. I suggest that disagreement may not deter integration and collaboration, but without addressing contestation over key discursive claims about how stormwater governance should proceed, broadly accepted outcomes may remain elusive. 


\section{DISCOURSE AND ENVIRONMENTAL GOVERNANCE}

This paper engages with recent calls within urban political ecology to engage with the discursive practices and knowledge systems that shape urban ecologies, subjects, and practices (Gabriel, 2014; Grove, 2009; Lawhon, Ernstson, \& Silver, 2013). Drawing on Hajer (1995, p. 44), I consider discourse "a specific ensemble of ideas, concepts and categorizations that are produced, reproduced and transformed in a particular set of practices and through which meaning is given to physical and social realities." A key to this understanding is that multiple discourses exist, each competing to leverage their authority over the other in determining environmental outcomes. Discourses, however, are not merely statements; they enable and constrain what can emerge from a field of possibilities (Barad, 2003; Müller, 2008). It is when particular discourses are adopted and advocated for, especially by powerful interests and political institutions, that some discourses emerge as legitimate possibilities while others are rendered unsuitable (McDonald, 2013; Robbins, 2006).

Within political geography and political ecology, a focus on discourse underscores the importance of language and practice in shaping social and material outcomes (Müller, 2008). Studies indicate how ecological understandings are transformed through institutional arrangements (Sneddon \& Fox, 2006) and how new networks arise through the scaling and rescaling of environmental governance (Bulkeley, 2005). Scholars have also demonstrated how the formation of 'discourse coalitions' link disparate political actors around shared narratives or framings to foster changes in environmental governance and policy making at a variety of scales (Bulkeley, 2000; Hajer, 1995). Others, however, warn that these discursive alliances often reflect 
idiosyncratic perspectives that reveal deeper divisions between power and knowledge (Robbins, 2006). Yet others contend that discursive disagreement does not deter collaboration, but it does make synergistic environments potentially more difficult to come by (Lansing, 2013). Central to these debates are a focus on the ways idiosyncratic experiences are expressed in relation to one's structural position and how discourse shapes development practices.

While structural position may help predict ones discursive stance in policy debates, discourse alliances are often constructed in contradictory systems of power and knowledge that form and reproduce identity (Brannstrom, 2011; Robbins, 2006). To describe this contradictory phenomena of collaboration without consensus, scholars often point towards the creation and use of boundary objects to bridge diverse social worlds by enabling dialogue across groups around a shared, but flexible, item or concept, such as watersheds or water quality (Cohen \& Bakker, 2013; Freitag, 2014; Star \& Griesemer, 1989). While decision-making and collaboration is often messy and filled with uncertainty (Kingdon, 1984), it is also an arena where the evolving relationship between power and knowledge reworks the subjective relationships between people and the material world (Lemos and Agrawal, 2006; Agrawal, 2005).

Scholars focusing on urban water governance have drawn on these debates to highlight the power relations embedded among different discourses and how that influences the development of different responses to environmental challenges (Bakker, 2013; Kaika, 2003; Loftus, 2014). Ranganathan (2015), for example, demonstrates how flood risk is rooted not only in a legacy of colonial planning discourse directed at 'encroachers', but also materially through the assemblage of storm drains in Bangalore. 
Cousins (2016) also, shows how stormwater governance is shaped by technopolitical discourses centered on efforts to control the volume of urban stormwater runoff.

Finewood (2016), similarly captures how alternative forms of urban greening, such as green infrastructure, are maintained by a grey epistemology, which impedes democratic processes through its focus on technical and abiotic properties of stormwater conveyance. Others, such as Karvonen (2011), have also revealed how stormwater's multifaceted sociotechnical nature defies simple descriptions and categorizations, complicating its management.

In this paper, I draw on this work to examine how different epistemic communities construct their worldviews and interact across scales in their efforts to control stormwater. Yet as stormwater has emerged as an object of concern among a range of constituencies, so too have the range of discursive possibilities for resolving stormwater dilemmas in the city. Basic to this investigation is an identification of the field of possibilities that exist across different actors concerned with controlling the flow of stormwater in Los Angeles and other cities. Still, these possibilities are structured not only across the range of actors involved in shaping stormwater governance, but also across individuals themselves. In part, this study is about how individuals identify themselves with a set of discourses and how that enables and constrains their actions and beliefs. This offers multiple subject positions for identification, as well as an examination of how different discourses carry a set of valid knowledge claims, which establish some types of interventions as salient and credible while rejecting others (Cash et al., 2003; Dryzek, 1997; Hajer, 1995; McDonald, 2013). 
FRAMING STORMWATER AND ENVIRONMENTAL GOVERNANCE IN LOS ANGELES

Stormwater is an often-overlooked aspect of Los Angeles's history and politics of water resources development. With urbanization, came the expansion of impervious surfaces and the channelization of waterways to handle increased surface water flows and to mitigate flooding. Each profoundly altered drainage patterns, impacted water quality, and reduced groundwater recharge across the region (Dallman \& Spongberg, 2012). Typical of many cities, urban stormwater drainage in Los Angeles utilized drains, pipes, floodwater channels, and other engineered systems to encourage flood-protected development.

Stormwater is a complicated governance problem due to the diverse range of actors working at multiple levels of governance, each competing to leverage their influence over decision-making. As Table 1 shows, a wide range of roles and functions exist at every level of governance. Increasingly, the Los Angeles region is under pressure to capture more stormwater to augment supplies while simultaneously reducing flood impacts and meeting water quality regulations under the Clean Water Act (CWA). In California, the Porter-Cologne Act of 1969, and the 1972 amendments to the Federal Water Pollution Control Act, which form the modern CWA, granted power to the State Water Resources Control Board to regulate water quality and beneficial uses of California waters. Both statutes focused on improving water quality by regulating discharges of pollutants from factories and other 'point' sources of pollution into waterways. Nine different Regional Water Quality Control Boards are tasked with implementing federal and state water quality regulations in California.

[Table 1 here] 
Stormwater, however, was exempted by the United States Environmental Protection Agency (USEPA) in the early iterations of the CWA, but was overturned in 1977 through litigation by the Natural Resources Defense Council (NRDC). This case, known as $N R D C v$. Costle, required the USEPA to incorporate stormwater pollution (Solorio, 2012). Subsequently, in 1987 the CWA was amended to require the USEPA to issue National Pollutant Discharge Elimination System (NPDES) Municipal Stormwater permits for discharges from large Municipal Separate Storm Sewer Systems (MS4s). The NPDES permits are designed to ensure that stormwater discharges into rivers, lakes, or the ocean meet water quality standards. The Los Angeles Regional Water Quality Control Board issued the first NPDES Permit for Los Angeles County and its 84 incorporated cities in 1990 (Brandt, 2015), requiring a decrease in pollutants in stormwater and urban runoff. The MS4 permits continue to serve as the primary regulatory mechanism to address water quality and drive stormwater abatement goals.

The establishment of this system of federal and state regulation, however, marked the beginning of intense debate and controversy over the responsibility of cities to control the volume of stormwater discharges (Cousins, 2016). In Los Angeles, the Department of Public Works' Watershed Protection Division developed stormwater abatement programs to comply with the MS4 permits (Solorio, 2012). In 1998, Los Angeles adopted measures to enforce the NPDES permit and take punitive action against serious offenders (Brandt, 2015). This discourse of regulation has focused on numerical and calculable effluent limitations, such as Total Maximum Daily Loads (TMDLs), which are implemented through the NPDES permitting system and set numerical limits on the maximum amount of a pollutant that a water body can receive. The NRDC and the Santa Monica 
Baykeeper, for example, used this structure to file suit against the Los Angeles County Flood Control District for being in violation of their 2001 NPDES permit—due to the recording of pollution levels above their limitations (Boxall, 2014). More recently, the 2012 permit incorporates 33 TMDLs and designated the Los Angeles County Flood Control District, the County of Los Angeles, and 84 incorporated cities within the Los Angeles County Flood Control District with the exception of the City of Long Beach, as permittees (Geosyntec, 2014). When it is discovered that a discharger is causing or contributing to a violation of water quality standards and limitations, that entity is potentially subject to enforcement by the water boards or through a citizen suitregardless of whether or not the discharger is engaged in the process of mitigating impacts (SWRCB, 2015).

This discourse of stormwater governance, however, has predominantly focused on the water quality aspect of stormwater at the expense of water supply and environmental justice concerns (Kamieniecki \& Below, 2008). Given the context of current and future water scarcity in the region, however, successfully integrating stormwater into supply sources, as well as into new institutional structures, will be key for sustaining human, economic, and ecological health. Furthermore, the efficient use of stormwater, as an economic input with social-ecological benefits, is one strategy local, state, and federal institutions are advocating for as a means to meet the dual water supply and water quality challenge in Los Angeles (Cousins \& Newell, 2015). The demands of the approach on the city to invest in ways to capture, cleanse, and restore water, while mitigating flood risk, generates a range of vested and interested actors in the future of stormwater, each with their own distinct preferences and perspectives. These range from market based 
approaches like mitigation banking to citywide ordinances and rebates to incentivize stormwater capture projects, as well as reforming current regulatory structures.

\section{Mitigation Banking}

Mitigation banking schemes are driven by a discourse of market environmentalism that views continued economic growth as synergistic with the reduction of environmental impacts (Bakker, 2005). The focus of the approach is on developing private markets to encourage investments in green infrastructure and on leveraging private capital to reach clean water goals. The credit banking schemes work by allowing developers to meet LID requirements established under MS4 permits by paying into a bank and operate similar to traditional mitigation banking schemes (cf. Robertson, 2004). For example, 'mitigation credits' are created when a stream or wetland is restored at an off-site location or in addition to managing on-site stormwater management requirements. These credits can then be bought and sold by City and County agencies to offset their development and infrastructural projects. The demand for stormwater banking credits primarily comes from developers and agencies who can purchase the credits as a means to comply with their permit conditions under the CWA.

Advocates argue that mitigation banking offers numerous benefits to market participants by allowing property owners and developers to buy and sell credits in a manner that allows them to determine the most cost effective means for achieving stormwater mitigation goals (LABC, 2015; Valderrama et al., 2013). The objective is to provide an off-site alternative that allows developers and agencies to meet some, or all, of the stormwater regulatory requirements through these schemes. Mitigation banks are also advocated for as a method to provide more flexibility in fulfilling conditions under the 
CWA. The USEPA (1995), for example, states that mitigation banks "can bring together financial resources, planning and scientific expertise not practicable to many projectspecific compensatory mitigation proposals" and "increase the potential for the establishment and long-term management of successful mitigation that maximizes opportunities for contributing to biodiversity and/or watershed function."

Critics maintain that by allowing developers and property owners to purchase credits to meet LID requirements under current MS4 permits some actors are able to avoid implementing on-site mitigation measures, which can be time-consuming and unpredictable (Lave, 2012). Also at stake are issues of commensurability. One the challenges of mitigation banking (stormwater, streambank, or wetland) are establishing ecological equivalencies between the altered ecological system and the ecological system to be restored (Lave, 2012). These challenges present important differences in stakeholder perceptions of whether stormwater mitigation should occur off-site or on-site, and highlight the complicated nature of establishing environmental governance schemes that bring together different levels of government and the private sector (Robertson, 2004, 2012).

\section{Centralized and Decentralized Approaches}

Similarly, centralized approaches versus decentralized and distributed approaches towards stormwater capture and abatement divide actors. Centralized approaches focus on structural features that promote conveyance and retention. These include sewers and catchment basins along with treatment facilities, and in Los Angeles where most of the precipitation falls within a short seasonal period; many actors focused on supply perceive centralized infrastructures as the most desirable option to capture large amounts of run- 
off. As one state actor noted, "you need big to capture big" (interview, July 2014). In contrast, many NGOs, non-profits, and other organizations focused on water quality tend to prefer distributed or decentralized approaches, which include bioretention ponds and other features typically associated with green infrastructure that can capture stormwater at its source. While a shift from large centralized infrastructural systems to more distributed technologies is widely accepted as a key component to more sustainable water management (van de Meene et al., 2011), differences in actor preferences in Los Angeles present some contention among actors on the preferred means of capturing and cleansing stormwater.

\section{Integrated Management}

Emerging governance approaches such as IWRM, or so-called 'One Water' approaches, are also perceived unevenly among actors. The goal of IWRM is to promote the coordination and management of water, land, and related resources to advance economic and social welfare as well as maintaining the integrity of vital ecosystems (GWP, 2000; Mitchell, 2005). Informed by previous IWRM efforts and incentives in the current MS4 permit, Los Angeles is implementing a One Water LA plan as a means to integrate the management of the City's water resources and water infrastructure in an environmentally, economically, and socially beneficial manner (LA City, 2015).

Enhanced Watershed Management Plans (EWMPs) are also being rolled out as part of the City of Los Angeles's compliance with the Los Angeles County MS4 permit. Each EWMP is unique to a particular watershed (e.g. Upper Los Angeles River, Ballona Creek, and Santa Monica Bay) and identifies current and future multi-benefit projects that can meet water quality mandates. Overall, EWMPs offer a collaborative approach to 
decide upon a number of control measures, such as LID, GI, and centralized facilities for stormwater capture. While actors have a hard time disagreeing with any of these goals, many differ on the effectiveness or the means of achieving the goals of more sustainable and integrative approaches. Previous research has shown that collective agreement on the goals of government but disagreement on the means to achieve them can be held together by IWRM plans working as boundary objects (Ward, 2013), but this case demonstrates the complicated nature in which environmental governance unfolds as competing actors vie for position and power to achieve their goals.

\section{$\underline{\text { Rules, Rebates, and Ordinances }}$}

There is also a discourse on improving current city ordinances to encourage transitions at the household scale. For example, LADWP's (2015) Stormwater Capture Master Plan establishes citywide ordinances and rebates to incentivize stormwater capture projects and programs such as rain barrels, rain gardens, cisterns, and other residential improvements. Many of these distributed projects focus on enrolling citizens into programs designed to conserve and capture stormwater. With ongoing water supply challenges, capturing and harvesting rainwater helps conserve drinking water supplies and improve water quality. Approaches capable of achieving multiple-benefits is a key component of the City of Los Angeles's strategy to meet water quality standards in MS4 permits and maintain water supply reliability in the face of many climatic uncertainties.

As a whole, governance approaches to stormwater tend not to fit simple, easily describable categories, but instead vary across the range social and political of actors (Karvonen, 2011; van de Meene et al., 2011). In the following sections this article reveals how disparate understandings of stormwater are forged through different institutional 
arrangement and the ways multiple actors interact across scales of governance in Los Angeles.

\section{$\underline{\text { METHODS }}$}

This paper maps the structure of discourses among and between individual actors involved in shaping urban stormwater governance. In order to determine the range and intensity of discourses shaping stormwater governance my research progressed through multiple phases. The first phase of my research included archival research on governmental and non-governmental organizations that shape stormwater governance in Los Angeles and across the United States, such as the USEPA, United States Army Corps of Engineers (USACE), Los Angeles Department of Water and Power (LADWP), California State Water Resources Control Board, and the NRDC among other agencies and organizations. I then conducted semi-structured interviews with key actors and representatives from these, and other, organizations. I also attended meetings and workshops on stormwater management in Los Angeles and across the country. The results of the interviews, participant observation, and archival work were then analyzed to determine the different types of discourses and knowledge claims being made about how stormwater governance should proceed — not only in Los Angeles but also nationally. Following standard Q-methodology procedures, I assembled a concourse of statements from these sources and then narrowed concourse down to 40 representative statements, which captured the range and diversity of perspectives on stormwater management strategies, goals, challenges, and opportunities (Watts \& Stenner, 2012).

The second phase invited participants to sort the selected statements in a grid from +3 (most agree) to -3 (most disagree). In total, 27 participants took the survey, and 
they were purposively chosen based on their active role and affiliation with predominant environmental or planning NGOs, or with city, state, or federal departments or agencies involved in directing changes in stormwater governance in Los Angeles. This type of survey design is established among approaches concerned with revealing the diversity and range of discourses rather than the representative distribution of viewpoints across the population (Eden, Donaldson, \& Walker, 2005; Robbins \& Krueger, 2000; Webler, Danielson, \& Tuler, 2009). The chosen participants reflect the range of actor viewpoints structured across multiple scales and networks of governance, and the diversity of actors implicated in fostering changes in urban stormwater governance, from city level environmental groups to federal officials.

The next phase utilized PQMethod software to analyze the discursive alignments among the participants. Using this software, I used factor analysis to map the structure of discourses among the different participants. Factor analysis works by mathematically creating new variables, or factors, that explain variation among many variables (e.g. the participant responses). This analytical approach into subjectivity, known as Qmethodology, couples qualitative and quantitative techniques to reveal different arrangements of subject formation around a topic, instead of revealing the distribution of viewpoints across a population (S. R. Brown, 1980; Robbins, 2006; Watts \& Stenner, 2012; Webler et al., 2009). In this study, I used centroid analysis, over principal components analysis, because it offered more options for data exploration and is the only factor analytic technique available across other dedicated platforms for Q-methodological analysis (Watts and Stenner, 2012). By default, centroid analysis produces an unrotated factor matrix with seven extracted factors. Not all extracted factors, however, can explain 
variance. Four factors were retained based on the Kaiser-Guttman criterion, which posits that factors should only be retained if they have an EV of 1.00 or above (Guttman, 1954; Kaiser, 1960; Watts \& Stenner, 2012). This cut-off point ensures that every extracted factor represents more than one Q-sort. The unrotated factors were then rotated using varimax rotation. This common Q-methodology procedure extracts all significant factors and produces a factor solution that maximizes the amount of explained variance and the number of individuals associated with only one factor (Setiawan \& Cuppen, 2013; Webler et al., 2009).

The result produces an idealized sort, or factor array, for each group, which defines a distinct social perspective or discourse (Barry \& Proops, 1999). These discursive archetypes were then interpreted and refined based on six follow-up interviews and respondent comments provided at the end of the Q-sort, which asked each respondent to explain the statements they most agreed and disagreed with.

\section{RESULTS}

Results of the factor analysis determined four factors, or discursive alliances, representative of the range of variability in expert viewpoints. I define these four discursive groups as—Market Skepticism (D1), Managerial (D2), Market Technocracy (D3), and Regulatory and Administrative (D4) — account for 57\% of the variance (factor characteristics summarized in Table 2). The distinguishing statements that discursively define each group are shown in Appendix A, represented as an idealized sort for each group, indicating an association with specific perspectives and preferences towards stormwater problems and solutions. Each discursive group described below is outlined by 
these distinguishing statements (e.g. $(\# 3,-3)$ would mean the group is partly defined by a disagreement with statement number 3).

Actors across groups tend to agree that more integrated approaches are needed across all of the institutions and sectors concerned with the management of water, but their perspectives exist along a spectrum in their commitment towards certain discursive claims regarding the management of stormwater. Disagreements across perspectives also exist along a spectrum and arise over differences in the process and outcomes of more integrated approaches (e.g. types of infrastructure, the role of market and economic incentives, and the role of new institutions or rules to govern stormwater).

[Table 2 here]

\section{Discourse One: Market Skeptic}

This discourse is driven by stronger rules and regulations that can drive the development of integrated water resources management, rather than market approaches. The stance reflects a broader discourse of 'hydro-reformism' that is skeptical of market-oriented approaches and motivated to alter regulations (Cousins, 2017). Respondents who align with this discourse include two academics, six representatives from environmental NGO's engaged in advocacy, education, policy, and one regional government stakeholder. This group also contains actors who are often in conflict over the role of liability in stormwater management. For example, this discourse aligns representatives from both the plaintiff and the defendant of a high profile case over liability for discharges of pollutants into local waterways that exceeded provisions under the CWA. Post-sort interviews reveal that a shared dissatisfaction with current regulations and a 
desire for more clear and strict rules and regulations brings these two competing actors together.

A distinctive perspective among this group is that centralized urban water systems are maladapted to address climate change impacts and environmental stressors $(\# 29,+1)$. The problem, as one NGO official noted, is that centralized infrastructure is "typically single purpose and usually destroys or eliminates other services." Distributed green infrastructure projects are the preferred option for stormwater as the respondent goes on to say "because [green infrastructure] and distributed stormwater projects seek to preserve multiple benefits and services" (Respondent 14, April 2016). As a result, green infrastructure and LID projects are typically viewed as a more cost-effective approach by preserving and allowing ecological processes to provide water retention, filtration, and bioremediation services. While space for these projects is recognized as a significant hurdle for implementation within the city, it is not recognized as a major limiting factor $(\# 4,-2)$. A shared sentiment among the group is that effective green infrastructure can occur in small spaces and creative solutions can be developed to scale-up distribute stormwater projects to fit into the available spaces in the city $(\# 33,-2)$.

This group of actors also shows ambivalence, in comparison to other groups, in terms of their perception of incentive programs. They neither agree nor disagree that getting people to apply for incentive programs is problematic because people do not care about stormwater management or lack knowledge of water issues $(\# 8,0)$. Actors in follow-up interviews agree that people tend to respond well to incentive programs in southern California, but more distributed green infrastructure projects are still needed to 
engage community members about retaining and using stormwater in their neighborhoods.

What is unique about this perspective, however, is that it rejects market-oriented approaches over improved rule making and regulations. In contrast to the other discourses, they agree that stormwater, or water more generally, should not be guided by market, economic, or financial principles $(\# 17,+1)$. Corporate or private actors are also seen as unfit actors to have input on stormwater abatement targets they are held accountable to. For many in this perspective, too many loopholes in the current regulatory structure already exist for regulated parties to escape responsibility.

Market Skeptics also disagree that the development of a tradable credit system, with appropriate regulatory safeguards, will encourage investment in green infrastructure and help deliver stormwater mitigation at the lowest possible cost (\#12, -1). Similarly, they do not view the development of a mitigation bank for stormwater management as a way to foster public-private partnerships to address stormwater by allowing developers to meet LID requirements by paying into a bank (\#16, -1). Overall, Market Skepticism frames a cautious narrative of market-oriented approaches and of corporate and private interests to influence stormwater management. As one NGO official noted:

Corporations and private interests are looking to maximize profits or minimize costs and not sustain the health of the watershed that is being managed. It is understandably difficult to attach an economic cost to the value of a healthy watershed system. Corporate or private interests should be the last to have input on stormwater abatement targets they are held accountable to. (Respondent 18, April 2015)

\section{Discourse Two: The Managerialist}

The Managerial discourse favors large centralized projects for stormwater capture and market and data-driven approaches for stormwater management. The discourse articulates 
stormwater as underutilized resource that needs to be captured and stored for water supply benefits (Cousins, 2017). Actors also support integrated approaches, but they do not see 'One Water' approaches as the answer $(\# 18,-2)$. Collectively, this group includes four respondents. Three of these respondents work in different capacities for LADWP in regards to stormwater. The other respondent formerly worked for a large water utility, but now focuses on advocacy and education on water resource challenges across California.

A distinguishing perspective articulated by this discourse is that larger centralized projects for handling and capturing stormwater are typically more cost-efficient than trying to treat it at thousands of small sources and that they make more financial sense than distributed and decentralized stormwater projects $(\# 30,+3 ; \# 31,0)$. As one official noted after the sort, "I strongly agree that centralized projects are much better at handling stormwater cost-effectively compared to distributed projects and LID. This is easily seen as a cost-benefit analysis when considering [the] amount of water capture [for flood control] and infiltrated [for water supply]" (Respondent 12, April 2015). This respondent's viewpoint is supported in LADWP's Stormwater Capture Master Plan, which indicates many of the centralized projects are more cost-effective (Geosyntec, 2014). The preference for centralized projects, however, is rooted in the potential the infrastructures creates for providing water supply benefits. This perspective views big systems, such as dams and reservoirs, as important for flood control and stormwater mitigation. How that captured water is handled after precipitation events, however, is important for water supply $(\# 28,+3)$, regardless of whether it is captured on-site or offsite. Moving away from the centralized model towards distributed capture projects is not perceived as a way to improve the resiliency of urban water systems $(\# 32,-2)$. 
To accomplish stormwater management goals related to both water quality and quantity, the Managerialist perceives increased regulation as a significant barrier $(\# 1,+1)$. This includes approaches that perceive wastewater, water supply, floodwater, and water quality as 'One Water'. Respondents are also opposed to creating new institutions or rules to manage stormwater in a diverse landscape where too many agencies a perceived to exist already $(\# 36,+2)$. As city official respondent noted, "I am opposed to creating another agency to manage stormwater. There is already enough redundancy and the primary agencies routinely work together" (Respondent 11, April 2015).

As an alternative, the Managerialist perceives market approaches and improved data as the means to foster more effective stormwater management. Respondents in this group agree that decision-makers lack the data needed to adopt and accurately quantify green infrastructure's performance $(\# 3,+2)$. As a result, the Managerialist tends to disagree that engineers do not see green infrastructure as part of the solution $(\# 7,-3)$, but instead as one respondent noted, "when it comes to decision-making, particularly of public funds, measurable and tangible benefits are much easier to argue for" (Respondent 12, April 2015). In lieu of improved data, the Managerialist sees market based approaches as a key mechanism fostering transitions. This may also include allowing corporations and private interests an opportunity to develop targets for stormwater abatement $(\# 15,+1)$. Actors disagree that getting people to apply to incentive programs is problematic because people do not care about stormwater management or lack knowledge of water issues $(\# 8,-3)$. Rather a shared sentiment among the group is that incentive programs are successful ways to encourage distributed projects, improve 
knowledge, and not place a fee on taxpayers who may not understand the benefits of stormwater fees.

\section{Discourse Three: Market Technocrat}

This discourse reflects a commitment towards market environmentalism. The viewpoint shares a preference for market-oriented approaches with the Managerialist discourse, but differs in its preference for new institutions. Three respondents' sorts correlated significantly with this group. One participant is a municipal water official, another is a federal official, and the final respondent works for a large environmental NGO focusing on range of advocacy and litigation efforts in Los Angeles.

For those identifying with this position, resolving stormwater problems is centered on developing proper environmental regulations and market mechanisms. Respondents agree that stormwater management needs economic instruments to put a value on stormwater to make it into a resource $(\# 14,+3)$. A preferred approach is the development of a tradable credit system, with appropriate regulatory safeguards, to encourage investment in green infrastructure $(\# 12,+3)$. Similarly, respondents sharing this view see the development of a mitigation bank for stormwater as an important means to foster public-private partnerships to address stormwater by allowing developers to meet LID requirements by paying into a bank $(\# 16,+2)$. Not surprisingly then, the Market Technocrat also agrees more strongly than the other groups in allowing stormwater mitigation to occur off-site $(\# 24,+1)$. The development of off-site mitigation credit and banking programs are advocated for by both the NRDC and the USEPA, indicating that these perspectives reflect their structural position rather than an 
idiosyncratic position (Brannstrom, 2011; EPA, 2015; Lansing, 2013; Robertson, 2004; Valderrama et al., 2013).

The resulting picture of stormwater management is one of developing off-site mitigation and credit trading programs capable of expanding the green infrastructure retrofit market (Valderrama et al., 2013). The problem for this group is not a lack of data or too many rules $(\# 3,-1)$. Instead the problem is developing the right set of new institutions and rules, along with stormwater fees, to effectively provide the financial tools necessary to fund and manage stormwater $(\# 36,-2 ; \# 22,-3)$. As one respondent noted: "fewer government regulations is not going to solve our stormwater issues. Stormwater fees are based on a service that is necessary and can provide a source of funds for improvement projects. Stormwater fees can also be structured in a way to incent positive behaviors" (Respondent 8, April 2015). In this regard, the discourse seeks to engage community actors to fostering better outcomes, but primarily through incentives and other market approaches, as a key $(\# 25,+2)$.

The Market Technocrat is also unique in its relative ambivalence towards approaches that view wastewater, water supply, floodwater, and water quality as 'One Water' $(\# 18,0)$. In follow-up interviews, a shared sentiment was that integrated approaches are necessary, but 'One Water' approaches will not be effective without the proper financial instruments and incentives to foster successful management.

Respondents are also ambivalent in their attitudes around adequate space in the city (\#4, $0)$.

Discourse Four: The Regulatory and Administrative Technocrat 
This group is focused on addressing land-use challenges in the near term and utilizing data-driven approaches to manage stormwater. Four respondents' sorts correlated significantly with this group, including two municipal officials and two state officials. What defines this group, however, is an 'administrative rationalism' that emphasizes expert control in problem solving through traditional bureaucratic and regulatory structures and agencies (Dryzek, 1997).

This discourse constructs stormwater problems as a lack of regulations and approaches to alter land-use. The Regulatory and Administrative Technocrat perceives land-use as one of the most difficult challenges to stormwater management $(\# 6,+1)$. In particular, finding space within the city to implement green infrastructure or other forms of LID to mitigate stormwater is perceived as a significant limitation $(\# 4,+3)$. One respondent noted in a post-sort interview, "more work needs to be made to integrate landuse planners and City planners with water purveyors to fully integrate watershed management for its resilience" (Respondent 17, April 2015). For those identifying with this discourse, incorporating the water purveyors is vital for proper stormwater management, as they have a set of customers to which fees can be assessed and incentive programs directed. This overcomes concerns among this group about the allocation of funds across other city services such as emergency services and recreation $(\# 35,0)$, of getting people to apply incentive programs $(\# 8,+1)$, and over the feasibility of stormwater fees $(\# 22,-3)$.

Resolving stormwater problems are about utilizing data driven and fact-based approaches to ensure that stormwater discharges generated from various land-uses do not exceed MS4 regulatory requirements $(\# 11,+3)$. This discourse is reflected in the Los 
Angeles MS4 permit, which states that, "Permittees shall coordinate with the local water purveyor(s), where applicable, to promote landscape water use efficiency requirements for existing landscaping, use of drought tolerant, native vegetation, and the use of less toxic options for pest control and landscape management." In particular, this discourse prefers establishing land-use approaches that hold and retain water on-site rather than offsite in order to achieve these goals $(\# 23,+1 ; \# 24,-2)$.

A distinguishing perspective of this discourse, however, is a strong disagreement with the statement that climate uncertainty is the most difficult challenge for proactive adaptation planning for stormwater management $(\# 5,-3)$. These respondents understand that climate change is going to present many challenges in the future, but it is perceived at a longer time-scale. As one respondent noted, "Climate uncertainty is not important to me at this time, as it potentially may become a problem, but only in the very long term. The real challenge is to figure out what to do over the next 10-20 years, and, in short, make sure that it will work" (Respondent 27, April 2015).

The resulting picture of stormwater articulated by this discourse is one of resolving land-use liabilities in the near term and establishing the proper regulations and relationships to meet requirements in the Los Angeles MS4 permit. Climate change, while a concern, is a longer-term challenge. Instead, efforts focus on short-term challenges centered on meeting regulatory requirements and justifying public expenditures on infrastructure to manage stormwater.

\section{DISCOURCE DIVERGENCE}

The results indicate important divergences in conceptual framings among groups. First, there is a division amongst the actors in the way they perceive and understand the role of 
new institutions and rules to manage stormwater. Social perspectives appear split with the Market Skeptic and Market Technocrat favoring new institutions and rules while the Managerialist and Regulatory and Administrative Technocrat seem relatively opposed to new institutions. Similarly, there is a lot of variability among actors who are opposed to creating new institutions or rules due to the amount of institutional diversity that already exists. The most striking difference is between the Managerialist and Market Technocrat. The Market Technocrat shares with the Market Skeptic an understanding that current regulations are not satisfactory or strict enough and allow pollution at levels that endanger the environment and human health. In contrast, the Managerialist sees too much redundancy in current institutional frameworks and perceives some regulations as hindering other priorities, such as water supply. This has the potential to lead to conflict as competing objectives, such as water quality, water supply, land-use, or flood control, vie for limited resources (Hanak et al., 2011). Interviews suggest this is a major source of contention among and between governmental and non-governmental agencies. While actors across perspectives agree that funds for stormwater should ensure multiple benefits - flood control, water supply, water quality, and urban greening - disagreement emanates from the perceived rigor of new and current institutional frameworks. Opposition by NRDC staff, for example, on new rules to capture and reuse stormwater in Los Angeles County stems from the way the new rules diminish the state's ability to enforce water quality standards (Morin, 2015).

This is mirrored in disagreement among actors over rules and regulations presenting barriers to management. The Market Skeptic presents some interesting contradictions in regards to this, which could also partly explain some of the 
disagreement over the role of new institutions. The Market Skeptic perceives increased regulations as a barrier to proper stormwater management while also maintaining that stricter laws and rules are also needed. This is an interesting paradox and is revealing for important reasons. Post-sort interviews indicate that increased regulations are often a barrier when it comes to increasing water supply, but to drive water quality and conservation measures, stricter laws and rules need to be put into place. In other words, rules and regulations both enable and constrain some actors, such as the supply agencies who feel that regulatory pressure may diminish the amount of water they can import but also require firmer rules to drive water quality and conservation measures.

Yet for others, disagreement on the role of new institutions is simply a matter of process. As one NGO official noted, "integration of institutions that work separately or at cross-purposes is the first step. New institutions come second" (Respondent 9, April 2016). One such institutional mechanism to foster integration and guide environmental action is the development of 'One Water' approaches. The goal is to render greater financial resources available across all sectors concerning water resource management by developing projects that are multi-beneficial. Actors across all social perspectives agree that more integrated approaches are necessary, but again the Managerialist shows a contradiction in statements and disagrees with the statement that one-water approaches are a more efficient approach. This disagreement is most prevalent between the Market Skeptic and the Managerialist, where the perspectives diverge on concerns over water quality and water quantity. In post-sort interviews, a city official indicated that "One Water lingo [is] not the answer. The money is there from the agencies and the planning is taking place already" (Respondent 23, April 2015). Others indicated that managing 
stormwater for multi-beneficial use is the goal of both integrated approaches and 'One Water' approaches. When supply agencies, like LADWP, look to invest in a project, however, they have to analyze the cost specifically for water supply benefits. As one city official noted

We do not quantify any other benefits such as water quality, habitat restoration, flood control, etc. Not that those aren't important, if a project has multi-benefits, the more attractive it looks. But we primarily focus at volumes of water being produced for water supply. That is how we are able to justify expenditures to our governing board. (Respondent 11, June 2014).

While the Managerialist welcomes integrated or 'One Water' approaches, perspectives focused more strongly on supply rather than water quality presents mixed perspectives. Water suppliers, for example, tend to view these projects positively only when it meets a certain water supply benefit.

Disagreement also stems from competing infrastructural visions. Not surprisingly, the Managerialist prefers large centralized projects for handling and capturing stormwater while the other groups tend to prefer decentralized approaches. This is a serious point of contention between social perspectives. Managerialists rely on their cost-benefit analyses to argue for their cost effectiveness and role in increasing supply. As noted earlier, however, environmental justice concerns surrounding the costs and benefits of improved water quality and other benefits are not quantified into these metrics (Kamieniecki \& Below, 2008). This leads some actors to claim for the effectiveness of large-scale infrastructure while others are arguing that such claims, "have no foundation in reality" (Respondent 39, April 2015). The other perspectives perceive distributed options as the most cost-effective way to achieve multiple benefits. Yet some disagreement remains in regards to whether projects should manage stormwater on-site or off-site via centralized 
regional projects (\#24). Centralized regional projects would be capable of capturing larger volumes of water, but many actors are concerned over the liability and legal challenges of implementing off-site approaches. Perspectives seem split over the ability of infrastructural projects to capture enough water to provide a supply benefit with those concerned over liability and legal challenges related to water quality.

Finally, there are important differences between social perspectives on the role of market and economic mechanisms to manage stormwater. Those that took a positive and optimistic stance towards market and economic approaches were mixed in their professional backgrounds, but post-sort interviews reveal a shared sentiment among all discourses, except Market Skepticism, that improved stormwater management is about developing the proper economic incentives. Instead, Market Skepticism maintains a more pragmatic and skeptical vision towards the difficulties and limits of market and economic approaches. These actors tended to have backgrounds in academic institutions or positions that frequently put them in contact with them. Post-sort interviews suggest that this gives them a better understanding of the difficulties of attaching an economic value to a healthy watershed. This does not mean that these actors are universally opposed to market and economic incentives - household incentives were generally viewed positively_ but they are skeptical towards approaches that may produce outcomes for actors to disproportionately profit. The differences are focused at the scale of management where incentives geared towards transforming stormwater into a resource at the household scale is positive, but market approaches at larger scales are viewed less favorably. Disagreement over the role of mitigation banking for stormwater is revealing in this regard. 


\section{DISCOURCE CONVERGENCE}

The results indicate that some perspectives on stormwater governance flow across disparate groups, both within and outside of formal institutions. Specifically, evidence suggests that IWRM is at the confluence of multiple perspectives on stormwater management. Actors across all perspectives resolutely agree that more holistic and integrated approaches are needed across all of the institutions and sectors concerned with the management of water. Science and data driven approaches, however, are considered the primary techniques required to integrate approaches. As one NGO official noted,

Science is objective and should always drive sound decision-making. That being said, additional data and science-based recommendations are needed to further the integrated, distributed, and green infrastructure approach. Integration or 'One Water' is key, but it is only as good as its components. (Respondent 25, April 2015)

The degree to which each of these 'components' aligns across perspectives varies,

however. The results indicate that how one comes to know and interact with stormwater through their structural position influences how they perceive stormwater. This lends some support to assertions that an actor's perspective towards an environmental issue is structural rather than idiosyncratic (Brannstrom, 2011; Lansing, 2013). As Brannstrom (2011: 543) notes, however, "structural position might help predict an actor's support for a social perspective, but the articulation of the ideas is idiosyncratic, particular, and based on broader knowledge claims." The implications for successful integrated approaches is understanding the specific issues where overlap occurs and where opportunities for boundary crossing exist (Ward, 2013). 
Some of the key components that actors broadly agree on are the multiple benefits distributed LID or green infrastructure offers cities as they scale up these approaches and the role of large technical systems such as dams to mitigate stormwater impacts. While the Managerialist shows a stronger preference for large centralized systems to generate supply, and some ambivalence towards distributed LID, respondents indicated in postsort interviews that their focus is typically on volumes of water produced for water supply. Projects that offer multiple benefits are desirable, but other benefits such as water quality, habitat restoration, and flood control typically are not quantified by the large supply agencies like LADWP. This orients their vision towards approaches that marshal stormwater as a supply. The fact that they see distributed projects as desirable and scalable, however, offers an important common ground for actors to come together. Another component actors tend to agree on is the need for economic instruments to put a value on stormwater and begin to utilize it as a resource. This is a key issue underlying many of the positions actors take. For instance, while actors tend to agree that cities need stormwater fees, the Managerialist's ambivalence towards them is not driven by a perceived lack of need. Instead, stormwater fees are perceived as part of a larger set of economic instruments that, as one respondent noted, "can be structured in a way to incent positive behaviors [in people and institutions]" (Respondent 8, April 2015). In addition to creating economic instruments to put a value on stormwater, actors see a need for stricter laws and regulations to address stormwater because they do not see change as happening voluntarily. The Market Skeptic and Market Technocrat most strongly share this sentiment and although the Regulatory and Administrative Technocrat ranked it as neutral, one respondent noted in a post-sort interview that increased regulation is needed 
alongside financial mechanisms to utilize stormwater as a resource. This indicates a broader perspective across groups of finding a balance between increased regulations and market approaches to manage stormwater. As one actor noted, "regulations are crafted to respond to societal needs when the market is either ineffective or hostile to resolutions; [increased] regulations are often necessary" (Respondent 1, April 2015).

Interestingly, however, actors tend to be ambivalent towards the role of NGOs and do not perceive green infrastructure and LID as influencing the social character of neighborhoods. Actor responses towards the role of NGOs were surprising considering that many of the respondents work for NGOs. In post-sort interviews, however, the answer became relatively straightforward: stormwater is perceived as a jurisdictional issue and NGOs cannot change the handling of stormwater without some of those issues being resolved. More critical, however, is agreement among actors that urban greening efforts are unlikely to alter the character of neighborhoods as more cities build more economic development around green space. This is contrary to evidence that has shown how urban greening can have unintended consequences such as gentrification (Wolch, Byrne, \& Newell, 2014) and that the financially better off are more likely to benefit from stormwater pollution controls in the Los Angeles region (Kamieniecki \& Below, 2008). The outcome is troubling, and raises concerns about current approaches, which may not adequately address equity issues and fully integrate the concerns of community stakeholders in formulating the outcomes of stormwater governance.

\section{CONCLUSION}


This article explored how a diverse group of stakeholders involved in stormwater management, from state bureaucrats to local environmental leaders, understand stormwater problems, their perspectives and preferences towards solutions, and how these perceptions relate to one another. As this study demonstrated, stormwater embodies a fluid set of meanings, problems, and solutions, which are framed differently across stakeholders. While stakeholders tended to agree that more integrated and data driven approaches are needed to achieve better outcomes, disagreement still arises over the means to achieve those goals. Important differences exist in terms of utilizing market mechanisms, such as mitigation banking, the cost-effectiveness of different types of infrastructure, and the role of new institutions and rules.

Amidst growing uncertainties over water resource flows in Los Angeles, and developing policy discussions articulating the ongoing cycles of flood and drought as the new normal, it is important to reflect on the broader significance of this case. Given the context of future water scarcity and changes in the size and frequency of storms across California (Hanak \& Lund, 2011), effectively integrating stormwater into current water management schemes will be crucial for both human and ecological health. The challenge will lie in developing collaborative approaches and institutions capable of ensuring success rather failure. Discursive agreement may not be necessary for some of the stakeholders in Los Angeles to collaborate, but establishing long-term success may very well be dependent on overcoming these differences. This study indicated some important points of convergence and divergence in stakeholder perspectives that may impede or facilitate desirable social and ecological outcomes in stormwater management. 
One of the central questions moving forward is in what ways will the power of some discourse coalitions legitimize some types of interventions as salient and credible while dismissing others (Cash et al., 2003; Hajer, 1995; Robbins, 2006). With current trends in environmental governance moving towards hybrid forms that bring together groups that transcend traditional organizational structures to include both public and private entities, it is yet to be seen how more sustainable outcomes will be achieved through current configurations of knowledge and power. Integrated water management has the potential to settle water conflict without litigation (Hughes \& Pincetl, 2013), but with most governance decisions occurring within existing infrastructural, political, and fiscal constraints, challenging some of the dominant and centralized approaches may prove difficult, despite efforts to be more integrated and holistic. Conflicts may arise over the costs and benefits of different types of stormwater interventions directed at water quantity and quality. As this study has shown, many differences across groups concerned about stormwater exist, and exactly how governance systems will adapt to changing social, political, and climatic realities is yet to be seen. 


\section{REFERENCES}

Agrawal, A., \& Lemos, M. C. (2007). A Greener Revolution in the Making?: Environmental Governance in the 21st Century. Environment: Science and Policy for Sustainable Development, 49(5), 36-45.

Bakker, K. (2005). Neoliberalizing Nature? Market Environmentalism in Water Supply in England and Wales. Annals of the Association of American Geographers, 95(3), 542-565. https://doi.org/10.1111/j.1467-8306.2005.00474.x

Bakker, K. (2013). Constructing "public" water: the World Bank, urban water supply, and the biopolitics of development. Environment and Planning D: Society and Space, 31(2), 280-300.

Bakker, K. (2014). The Business of Water: Market Environmentalism in the Water Sector. Annual Review of Environment and Resources, 39(1), 469-494. https://doi.org/10.1146/annurev-environ-070312-132730

Barad, K. (2003). Posthumanist Performativity: Toward an Understanding of How Matter Comes to Matter. Signs: Journal of Women in Culture and Society, 28(3), 801-831. https://doi.org/10.1086/345321

Barry, J., \& Proops, J. (1999). Seeking sustainability discourses with Q methodology. Ecological Economics, 28(3), 337-345.

Bell, S. (2015). Renegotiating urban water. Progress in Planning, 96, 1-28. https://doi.org/10.1016/j.progress.2013.09.001

Boxall, B. (2014, May 5). Supreme Court favors environmentalists in urban runoff case. Los Angeles Times. Los Angeles, CA.

Brandt, A. W. (2015). Stormwater and Green Infrastructure: The Next Generation of Los Angeles Stormwater Infrastructure. In American Bar Association Section of Environment, Energy and Resources (pp. 1-9). Chicago, Il.

Brannstrom, C. (2011). A Q-Method Analysis of Environmental Governance Discourses in Brazil's Northeastern Soy Frontier. The Professional Geographer, 63(4), 531549 .

Brown, R. R., Farrelly, M. A., \& Loorbach, D. a. (2013). Actors working the institutions in sustainability transitions: The case of Melbourne's stormwater management. Global Environmental Change, 23(4), 701-718. https://doi.org/10.1016/j.gloenvcha.2013.02.013

Brown, S. R. (1980). Political Subjectivity: Applications of Q-methodology in political science. New Haven: Yale University Press.

Bulkeley, H. (2000). Discourse coalitions and the Australian climate change policy network. Environment and Planning C: Government and Policy, 18(6), 727-748. https://doi.org/10.1068/c9905j 
Bulkeley, H. (2005). Reconfiguring environmental governance: Towards a politics of scales and networks. Political Geography, 24(8), 875-902.

Carlson, C., Barreteau, O., Kirshen, P., \& Foltz, K. (2015). Storm Water Management as a Public Good Provision Problem: Survey to Understand Perspectives of LowImpact Development for Urban Storm Water Management Practices under Climate Change. Journal of Water Resources Planning and Management, 141(6), 4014080. https://doi.org/10.1061/(ASCE)WR.1943-5452.0000476

Cash, D. W., Clark, W. C., Alcock, F., Dickson, N. M., Eckley, N., Guston, D. H., ... Mitchell, R. B. (2003). Knowledge systems for sustainable development. Proceedings of the National Academy of Sciences of the United States of America, 100(14), 8086-91. https://doi.org/10.1073/pnas.1231332100

Cohen, A., \& Bakker, K. (2013). The eco-scalar fix: rescaling environmental governance and the politics of ecological boundaries in Alberta, Canada. Environment and Planning D: Society and Space, 32. https://doi.org/10.1068/d0813

Cousins, J. J. (2016). Volume control: Stormwater and the politics of urban metabolism. Geoforum, c. https://doi.org/10.1016/j.geoforum.2016.09.020

Cousins, J. J. (2017). Structuring hydrosocial relations in urban water governance. Annals of the American Association of Geographers2. https://doi.org/10.1080/24694452.2017.1293501

Cousins, J. J., \& Newell, J. P. (2015). A political-industrial ecology of water supply infrastructure for Los Angeles. Geoforum, 58, 38-50. https://doi.org/10.1016/j.geoforum.2014.10.011

Dallman, S., \& Spongberg, M. (2012). Expanding Local Water Supplies: Assessing the Impacts of Stormwater Infiltration on Groundwater Quality. The Professional Geographer, 64(2), 232-249. https://doi.org/10.1080/00330124.2011.600226

Dryzek, J. S. (1997). The Politics of the Earth: Environmental Discourses. New York: Oxford University Press.

Eden, S., Donaldson, A., \& Walker, G. (2005). Structuring subjectivities? Using Q methodology in human geography. Area, 37(4), 413-422. https://doi.org/10.1111/j.1475-4762.2005.00641.x

EPA. Section 404 of the Clean Water Act: Federal Guidance for the Establishment, Use and Operation of Mitigation Banks (1995). Retrieved from https://www.epa.gov/cwa-404/federal-guidance-establishment-use-and-operationmitigation-banks-0

EPA. (2001). Source Water Protection Practices Bulletin: Managing Septic Systems to Prevent Contamination of Drinking Water. Retrieved from http://water.epa.gov/infrastructure/drinkingwater/sourcewater/protection/upload/stor mwater.pdf

EPA. (2014). Climate Change Adaptation Implementation Plan. Retrieved from http://epa.gov/climatechange/Downloads/OW-climate-change-adaptation-plan.pdf 
EPA. (2015). Mitigation Banking Fact Sheet. Retrieved August 1, 2015, from http://water.epa.gov/lawsregs/guidance/wetlands/mitbanking.cfm

Ferguson, B. C., Brown, R. R., \& Deletic, A. (2013). Diagnosing transformative change in urban water systems: Theories and frameworks. Global Environmental Change, 23(1), 264-280. https://doi.org/10.1016/j.gloenvcha.2012.07.008

Finewood, M. H. (2016). Green Infrastructure, Grey Epistemologies, and the Urban Political Ecology of Pittsburgh's Water Governance. Antipode, 48(4), 1000-1021. https://doi.org/10.1111/anti.12238

Freitag, A. (2014). Naming, Framing, and Blaming: Exploring Ways of Knowing in the Deceptively Simple Question “What is Water Quality?" Human Ecology, 42(2), 325-337. https://doi.org/10.1007/s10745-014-9649-5

Gabriel, N. (2014). Urban Political Ecology: Environmental Imaginary, Governance, and the Non-Human. Geography Compass, 8(1), 38-48. https://doi.org/10.1111/gec3.12110

Geosyntec. (2014). Stormwater Capture Master Plan Interim Report. Los Angeles, CA.

Greenaway, A., Allen, W., Feeney, C., \& Heslop, V. (2005). Learning Into a Low-Impact Future : Collaborative Approaches To Stormwater Management . NZWWA, 4th South Pacific Stormwater Conference on Stormwater and Aquatic Resource Protection, 4-6.

Grimm, N. B., Faeth, S. H., Golubiewski, N. E., Redman, C. L., Wu, J., Bai, X., \& Briggs, J. M. (2008). Global change and the ecology of cities. Science (New York, N.Y.), 319(5864), 756-60.

Grove, K. (2009). Rethinking the nature of urban environmental politics: Security, subjectivity, and the non-human. Geoforum, 40(2), 207-216. https://doi.org/10.1016/j.geoforum.2008.09.005

Guttman, L. (1954). Some necessary conditions for common-factor analysis. Psychometrika, 19(2), 149-161.

GWP. (2000). Integrated Water Resources Management: TAC Background Papers No. 4. Stockholm, Sweden.

Hajer, M. A. (1995). The Politics of Environmental Discourse: Ecological Modernization and the Policy Process. Oxford: Oxford University Press.

Hanak, E., Lund, J., Dinar, A., Gray, B., Howitt, R., Mount, J., ... Thompson, B. (2011). Managing California's Water From Conflict to Reconciliation. San Francisco, CA: Public Policy Institute of California.

Hanak, E., \& Lund, J. R. (2011). Adapting California's water management to climate change. Climatic Change, 111(1), 17-44. https://doi.org/10.1007/s10584-011-02413

Hughes, S., \& Pincetl, S. (2013). Evaluating collaborative institutions in context: the case 
of regional water management in southern California. Environment and Planning C: Government and Policy, 31. https://doi.org/10.1068/c1210

IPCC. (2014). Climate Change 2014: Synthesis Report. Contribution of Working Groups I, II and III to the Fifth Assessment Report of the Intergovernmental Panel on Climate Change. (R. Pachauri \& Meyer LA, Eds.). Geneva, Switzerland.

Kaika, M. (2003). Constructing Scarcity and Sensationalising Water Politics: 170 Days That Shook Athens. Antipode, 35(5), 919-954.

Kaiser, H. (1960). The application of electronic computers to factor analysis. Educational and Psychological Measurement, 20, 141-151.

Kamieniecki, S., \& Below, A. (2008). Ethical Issues in Storm Water Policy Implementation: Disparities in Financial Burdens and Overall Benefits. In J. M. Whitely, H. Ingram, \& R. Warren Perry (Eds.), Water, Place, and Equity (pp. 6994). Cambridge, MA: MIT Press.

Karvonen, A. (2011). Politics of Urban Runoff: Nature, Technology, and the Sustainable City. Cambridge, MA: MIT Press.

Kingdon, J. W. (1984). Agendas, Alternatives, and Public Policy. Boston, MA: Little, Brown, and Co.

LA City. (2015). Water Resources Planning: One Water LA Plan. Retrieved May 23, 2016, from https://www.lacitysan.org/san/faces/home/portal/s-lsh-es/s-lsh-esowla?_afrLoop $=25996330363457704 \&$ afrWindowMode $=0 \&$ afrWindowId $=$ null $\#$ !@@? afrWindowId=null\&_afrLoop=25996330363457704\&_afrWindowMode=0 \&_adf.ctrl-state=f8sorr00_161

LABC. (2015). LA's Next Frontier: Capturing Opportunities for New Housing, Economic Growth, and Sustainable Development in LA River Communities.

LADWP. (2015). Stormwater Capture Master Plan: The Master Planning Process Interim Report. Los Angeles, CA.

Lansing, D. M. (2013). Not all baselines are created equal: A Q methodology analysis of stakeholder perspectives of additionality in a carbon forestry offset project in Costa Rica. Global Environmental Change, 23(3), 654-663.

Lave, R. (2012). Bridging Political Ecology and STS: A Field Analysis of the Rosgen Wars. Annals of the Association of American Geographers, 102(2), 366-382. https://doi.org/10.1080/00045608.2011.641884

Lawhon, M., Ernstson, H., \& Silver, J. (2013). Provincializing Urban Political Ecology: Towards a Situated UPE Through African Urbanism. Antipode, O(0), 1-20. https://doi.org/10.1111/anti.12051

Lemos, M. C., \& Agrawal, A. (2006). Environmental Governance. Annual Review of Environment and Resources, 31(1), 297-325. https://doi.org/10.1146/annurev.energy.31.042605.135621 
Loftus, A. (2014). Water (in)security: securing the right to water. The Geographical Journal, n/a-n/a. https://doi.org/10.1111/geoj.12079

Loperfido, J. V., Noe, G. B., Jarnagin, S. T., \& Hogan, D. M. (2014). Effects of distributed and centralized stormwater best management practices and land cover on urban stream hydrology at the catchment scale. Journal of Hydrology, 519, 25842595. https://doi.org/10.1016/j.jhydrol.2014.07.007

Marlow, D. R., Moglia, M., Cook, S., \& Beale, D. J. (2013). Towards sustainable urban water management: a critical reassessment. Water Research, 47(20), 7150-61. https://doi.org/10.1016/j.watres.2013.07.046

McDonald, M. (2013). Discourses of climate security. Political Geography, 33(1), 4251. https://doi.org/10.1016/j.polgeo.2013.01.002

Milly, P. C. D., Betancourt, J., Falkenmark, M., Hirsch, R. M., Kundzewicz, Z. W., Lettenmaier, D. P., \& Stouffer, R. J. (2008). Climate change. Stationarity is dead: whither water management? Science (New York, N.Y.), 319(5863), 573-574. https://doi.org/10.1126/science.1151915

Mitchell, B. (2005). Integrated water resource management, institutional arrangements, and land-use planning. Environment and Planning A, 37(8), 1335-1352. https://doi.org/10.1068/a37224

Morin, M. (2015, June 17). L.A. County's plan to capture stormwater could be state model. The Los Angeles Times.

Müller, M. (2008). Reconsidering the concept of discourse for the field of critical geopolitics: Towards discourse as language and practice. Political Geography, 27(3), 322-338. https://doi.org/10.1016/j.polgeo.2007.12.003

Pahl-Wostl, C. (2007). Transitions towards adaptive management of water facing climate and global change. Water Resoources Management, 21(1), 49-62. https://doi.org/10.1007/978-1-4020-5591-1-4

Pataki, D. E., Carreiro, M. M., Cherrier, J., Grulke, N. E., Jennings, V., Pincetl, S., ... Zipperer, W. C. (2011). Coupling biogeochemical cycles in urban environments: ecosystem services, green solutions, and misconceptions. Frontiers in Ecology and the Environment, 9(1), 27-36.

Porse, E. (2013). Stormwater Governance and Future Cities. Water, 5(1), 29-52. https://doi.org/10.3390/w5010029

Ranganathan, M. (2015). Storm Drains as Assemblages: The Political Ecology of Flood Risk in Post-Colonial Bangalore. Antipode, 47(5), 1300-1320. https://doi.org/10.1111/anti.12149

Robbins, P. (2006). The politics of barstool biology: Environmental knowledge and power in greater Northern Yellowstone. Geoforum, 37, 185-199.

Robbins, P., \& Krueger, R. (2000). Beyond bias? The promise and limits of Q method in human geography. Professional Geographer, 52(4), 636-648. 
Robertson, M. (2004). The neoliberalization of ecosystem services: Wetland mitigation banking and problems in environmental governance. Geoforum, 35(3), 361-373. https://doi.org/10.1016/j.geoforum.2003.06.002

Robertson, M. (2012). Measurement and alienation: making a world of ecosystem services. Transactions of the Institute of British Geographers, 37(3), 386-401. https://doi.org/10.1111/j.1475-5661.2011.00476.x

Setiawan, A. D., \& Cuppen, E. (2013). Stakeholder perspectives on carbon capture and storage in Indonesia. Energy Policy, 61, 1188-1199. https://doi.org/10.1016/j.enpol.2013.06.057

Sneddon, C., \& Fox, C. (2006). Rethinking transboundary waters: A critical hydropolitics of the Mekong basin. Political Geography, 25(2), 181-202. https://doi.org/10.1016/j.polgeo.2005.11.002

Solorio, J. (2012). The Future of Stormwater: Capture, Store and Supply. Los Angeles, CA.

Star, S. L., \& Griesemer, J. R. (1989). Institutional Ecology, 'Translations’ and Boundary Objects: Amateurs and Professionals in Berkeley's Museum of Vertebrate Zoology, 1907-39. Social Studies of Science, 19(3), 387-420.

SWRCB. Waste discharge requirements for Municipal Separate Storm Sewer System (MS4) discharges within the coastal watersheds of Los Angeles County, except those discharges originating from the City of Long Beach MS4 (2015). Retrieved from http://www.swrcb.ca.gov/board_decisions/adopted_orders/water_quality/2015/wqo2 015_0075.pdf

Tompkins, E. L., Adger, W. N., Boyd, E., Nicholson-Cole, S., Weatherhead, K., \& Arnell, N. (2010). Observed adaptation to climate change: UK evidence of transition to a well-adapting society. Global Environmental Change, 20(4), 627-635. https://doi.org/10.1016/j.gloenvcha.2010.05.001

Valderrama, A., Bayon, R., Wachowicz, K., Kaiser, C., Holland, C., Kerr, O., ... Devine, J. (2013). Creating Clean Water Cash Flows Developing Private Markets for Green Stormwater Infrastructure in Philadelphia Authors, (january).

van de Meene, S. J., Brown, R. R., \& Farrelly, M. a. (2011). Towards understanding governance for sustainable urban water management. Global Environmental Change, 21(3), 1117-1127. https://doi.org/10.1016/j.gloenvcha.2011.04.003

Ward, L. (2013). Eco-governmentality revisited: Mapping divergent subjectivities among Integrated Water Resource Management experts in Paraguay. Geoforum, 46, 91102. https://doi.org/10.1016/j.geoforum.2012.12.004

Watts, S., \& Stenner, P. (2012). Doing Q Methodological Research: Theory, Method, and Interpretation. London: SAGE Publications.

Webler, T., Danielson, S., \& Tuler, S. (2009). Using Q Method to Reveal Social Perspectives in Environmental Research. Greenfield MA: Social and Environmental 


\section{Research Institute.}

Wolch, J. R., Byrne, J., \& Newell, J. P. (2014). Urban green space, public health, and environmental justice: The challenge of making cities "just green enough."

Landscape and Urban Planning, 1-11. https://doi.org/10.1016/j.landurbplan.2014.01.017

Appendix A. Factor array showing idealized Q-sort for each factor, or discursive group, in Los Angeles

\begin{tabular}{|c|c|c|c|c|c|}
\hline \multicolumn{2}{|c|}{ Statement } & \multicolumn{4}{|c|}{ Discourse Group } \\
\hline & & \multirow{2}{*}{$\begin{array}{r}\mathrm{D} 1 \\
-3\end{array}$} & \multirow{2}{*}{$\frac{\mathrm{D} 2}{1}$} & \multirow{2}{*}{$\frac{\text { D3 }}{-3}$} & \multirow{2}{*}{$\begin{array}{r}\mathrm{D} 4 \\
-1\end{array}$} \\
\hline 1. & One of our biggest barriers is increased regulation. & & & & \\
\hline 2. & $\begin{array}{l}\text { Implementation is a barrier in large part due to NIMBY type of concerns. People do not } \\
\text { want to be liable. }\end{array}$ & 0 & $\overline{1}$ & 1 & -1 \\
\hline 3. & $\begin{array}{l}\text { We lack the data needed for the adoption green infrastructure and to accurately quantify } \\
\text { its performance. }\end{array}$ & 0 & $\underline{\mathbf{2}}$ & -1 & 0 \\
\hline 4. & $\begin{array}{l}\text { The trouble within the city is that we're so congested and built up we don't have the } \\
\text { space for many types of green infrastructure; space is a significant limitation. }\end{array}$ & -2 & 2 & $\underline{\mathbf{0}}$ & 3 \\
\hline 5. & $\begin{array}{l}\text { Climate uncertainty is the most difficult challenge for proactive adaptation planning for } \\
\text { stormwater management. }\end{array}$ & 0 & 0 & 0 & $\underline{-3}$ \\
\hline 6. & Land-use change presents the most difficult challenge to stormwater management. & -1 & -1 & 0 & $\underline{\mathbf{0}}$ \\
\hline 7. & $\begin{array}{l}\text { I think there is a cultural problem. Stormwater engineers see only engineering solutions } \\
\text { and green infrastructure is not part of that. }\end{array}$ & 0 & $\underline{-3}$ & 0 & 0 \\
\hline 8. & $\begin{array}{l}\text { Getting people to apply to incentive programs is problematic because people don't care } \\
\text { about stormwater management and lack knowledge of water issues. }\end{array}$ & 0 & $\underline{-3}$ & -2 & 1 \\
\hline 9. & $\begin{array}{l}\text { We need stricter laws and regulations to address stormwater because change is not going } \\
\text { to happen voluntarily. }\end{array}$ & 2 & 1 & 2 & 0 \\
\hline 10 . & $\begin{array}{l}\text { Failure to address stormwater, like climate change, is a fault of political leaders; they are } \\
\text { the ones who need to be educated and incentivized to innovate. }\end{array}$ & 0 & -1 & 0 & -1 \\
\hline 11. & $\begin{array}{l}\text { Science and data should direct decisions on stormwater and infrastructure. We need data } \\
\text { driven and fact-based approaches drawing on the best available science and engineering. }\end{array}$ & 2 & 1 & 1 & 3 \\
\hline 12. & $\begin{array}{l}\text { Development of a tradable credit system, with appropriate regulatory safeguards, will } \\
\text { encourage investment in green infrastructure and help deliver stormwater mitigation at } \\
\text { the lowest possible cost. }\end{array}$ & -1 & 1 & $\underline{\mathbf{3}}$ & 1 \\
\hline 13. & We need market based approaches and fewer government interventions and regulations & -2 & 0 & -1 & -2 \\
\hline
\end{tabular}


to finance stormwater management.

14. Stormwater management needs economic instruments to put a value on stormwater and make it a resource rather than a hazard.

15. Corporations and private interests should have the chance to develop their own targets for stormwater abatement.

16. A mitigation bank for stormwater will help foster public-private partnerships to address stormwater by allowing developers to meet LID requirements by paying into that bank.

17. Stormwater, or water more generally, should not be guided by market, economic, or financial principles.

18. Wastewater, water supply, floodwater, water quality and all of that stuff is just water. If you just think of it as one water then you can manage it much more efficiently.

19. We don't need more integrated approaches. We need better enforcement of existing regulations and improvement of local codes and ordinances; integrated water resource planning is not the answer

20. An integrated management approach is critical. There needs to be a shift towards more integrated approaches across all of the institutions and sectors concerned with the management of water.

21. We need stormwater fees. Municipalities need fees and cost sharing plans.

22. Stormwater fees are not feasible, nor are they enough for successful implementation in the long term. Stormwater fees are problematic.

23. Stormwater needs to be held and used on-site; there are too many concerns about unregulated off-site mitigation.

24. Stormwater mitigation should be able to occur off-site; it offers more flexible opportunities. Off-site approaches lead to better outcomes than on-site.

25. We need to maintain the narrative of engagement by redefining city services and bringing the expertise to the neighborhoods. We need a grass roots community driven approach to create better outcomes.

26. Homeowners need to be educated and they need to educate each other about the benefits of improved stormwater management. They need to be the targets of interventions because community driven approaches tend to be more effective than data driven approaches.

27 Local residents' contributions to decision-making usually show a lack of expertise, are not factual, or biased.

28. Big systems and dams or reservoirs are important for floods and stormwater mitigation, but after the rain, how you handle that water is important for water quality and/or supply.

29 Centralized urban water systems are maladapted to address climate change impacts and environmental stressors.

30. Larger centralized projects for handling and capturing stormwater are typically more cost-efficient than trying to treat it at thousands of small sources. Centralized stormwater projects make more financial sense than distributed and decentralized stormwater projects.

31. LID offers economic benefits, such as deferring or even replacing costly large grey stormwater infrastructure projects. LID is more cost effective than gray infrastructure.

32. Resilience of urban water systems will be improved by moving away from the centralized model and using more distributed solutions like green infrastructure.

33. Distributed projects are not effective; they don't scale up across the city or to other sites and will never meet the level of stormwater abatement and/or capture needed.

34. As we build green infrastructure we are going to change the nature of neighborhoods. We are going to push working class people out as we build more economic development around green space.

35. For every dollar we spend on a water quality project that's one less emergency service dollar, recreation dollar, or funds for other services. It's hard to justify money for stormwater management.

36. I'm really opposed to creating new institutions or rules to manage stormwater. There are too many agencies and there is too much diversity already.

37. I think there definitely will be a need for new institutions and rules to manage stormwater.

38. With many community groups and NGOs there are issues with them maintaining the infrastructure or with them focusing too narrowly on certain issues.

\begin{tabular}{|c|c|c|}
\hline 1 & 1 & 3 \\
\hline-3 & $\underline{1}$ & -1 \\
\hline-1 & 0 & 2 \\
\hline 1 & -2 & -2 \\
\hline 3 & $\underline{-2}$ & 0 \\
\hline$\underline{-2}$ & -1 & -1 \\
\hline 3 & 2 & 2 \\
\hline 2 & 0 & 1 \\
\hline-1 & -1 & -3 \\
\hline 0 & -1 & -1 \\
\hline-1 & $\underline{\mathbf{0}}$ & 1 \\
\hline 1 & 0 & 2 \\
\hline 1 & 0 & 0 \\
\hline 0 & 0 & -2 \\
\hline 1 & 3 & 1 \\
\hline$\underline{1}$ & -1 & 0 \\
\hline-1 & $\underline{3}$ & -1 \\
\hline
\end{tabular}

$\begin{array}{cccc}2 & \underline{\mathbf{0}} & 2 & 2 \\ 1 & \underline{\mathbf{- 2}} & 1 & 1 \\ -2 & -1 & -1 & -1 \\ -1 & -1 & -2 & -2 \\ -2 & -2 & -1 & 0 \\ -1 & \underline{\mathbf{2}} & -2 & 0 \\ 1 & -2 & 1 & -2 \\ 0 & 1 & 0 & -1\end{array}$


39. I think there is enough NGO capacity within the city to have a better-coordinated and strategic approach to green infrastructure.

40. Rather than focusing on new development, we need to focus on the existing development and encourage retrofitting. Only looking at new developments hurts us.

Bold underlined are distinguishing statements (significant at $\mathrm{p}<0.05$ )

Table 1. Institutional actors. This table outlines the roles and functions of different actors at different scales of governance.

\section{Institutional Actors}

\begin{tabular}{lll}
$\begin{array}{l}\text { Scale of } \\
\text { Governance }\end{array}$ & Institutions and Entities & Roles and Functions \\
\hline
\end{tabular}

\begin{tabular}{|c|c|c|}
\hline National & $\begin{array}{l}\text { - Environmental agencies } \\
\text { - } \quad \text { Flood control agencies } \\
\text { - Legislative bodies } \\
\text { - Non-governmental organizations } \\
\text { Examples: US Environmental Protection Agency; US } \\
\text { Army Corps of Engineers }\end{array}$ & $\begin{array}{l}\text { Establish national } \\
\text { laws, rules, and } \\
\text { regulations (Clean } \\
\text { Water Act) }\end{array}$ \\
\hline State & $\begin{array}{c}\text { - Environmental agencies } \\
\text { - Water Management Agencies } \\
\text { - Legislative bodies } \\
\text { Example: State Water Resources Control Board (CA) }\end{array}$ & $\begin{array}{ll}\text { - } & \text { Regulatory } \\
\text { guidelines } \\
\text { - } & \text { Financing } \\
\text { - } & \text { Permitting } \\
\text { - } & \text { Flood management }\end{array}$ \\
\hline Region & $\begin{array}{l}\text { - } \quad \text { Government Councils } \\
\text { - Multi-agency working groups } \\
\text { Example: Los Angeles County Flood Control District; } \\
\text { Los Angeles Regional Water Quality Control Board }\end{array}$ & $\begin{array}{ll}\text { - } & \text { Permitting } \\
\text { Regional } \\
\text { Coordination } \\
\text { - Watershed }\end{array}$ \\
\hline
\end{tabular}




\begin{tabular}{|c|c|c|}
\hline & & management \\
\hline City & $\begin{array}{l}\text { - Water utilities } \\
\text { - City agencies and departments } \\
\text { Example: Los Angeles Department of Water and } \\
\text { Power; Los Angeles Department of Public Works }\end{array}$ & $\begin{array}{l}\text { - Local codes and } \\
\text { ordinances } \\
\text { Meet federal and } \\
\text { state mandates } \\
\text { - Fund infrastructure } \\
\text { development }\end{array}$ \\
\hline $\begin{array}{l}\text { Neighborhood, } \\
\text { community, } \\
\text { grassroots, and } \\
\text { land parcel }\end{array}$ & $\begin{array}{l}\text { - Homeowner's associations } \\
\text { - Businesses and groups } \\
\text { - Non-profits and NGOs } \\
\text { Examples: Water LA; LA Waterkeeper; Tree People }\end{array}$ & $\begin{array}{ll}\text { - } & \text { Taxes } \\
\text { - } & \text { Voluntary actions } \\
\text { - } & \text { Incentives }\end{array}$ \\
\hline
\end{tabular}

Table 2. The factor characteristics for each rotated factor, labeled here as discourse.

\begin{tabular}{lllll} 
Factor Characteristics & \multicolumn{3}{l}{ Discourse } \\
\cline { 2 - 5 } & $\mathrm{D} 1$ & $\mathrm{D} 2$ & $\mathrm{D} 3$ & $\mathrm{D} 4$ \\
\cline { 2 - 5 } Eigenvalue & 5.198 & 2.791 & 3.813 & 3.063 \\
No. of defining variables & 9 & 4 & 3 & 4 \\
Composite reliability & 0.973 & 0.941 & 0.923 & 0.941 \\
SE of factor scores & 0.164 & 0.243 & 0.277 & 0.243 \\
\% total variance & 19.992 & 10.737 & 14.665 & 11.783
\end{tabular}

